\title{
Effects of dietary crude protein and rumen-degradable protein concentrations on urea recycling, nitrogen balance, omasal nutrient flow, and milk production in dairy cows
}

\author{
T. Mutsvangwa, ${ }^{1}$ K. L. Davies, J. J. McKinnon, and D. A. Christensen \\ Department of Animal and Poultry Science, University of Saskatchewan, Saskatoon, SK, S7N 5A8, Canada
}

\begin{abstract}
The objective of this study was to determine how interactions between dietary crude protein $(\mathrm{CP})$ and rumen-degradable protein (RDP) concentrations alter urea-nitrogen recycling, nitrogen $(\mathrm{N})$ balance, omasal nutrient flow, and milk production in lactating Holstein cows. Eight multiparous Holstein cows $(711 \pm 21 \mathrm{~kg}$ of body weight; $91 \pm 17 \mathrm{~d}$ in milk at the start of the experiment) were used in a replicated $4 \times 4$ Latin square design with a $2 \times 2$ factorial arrangement of dietary treatments and 29-d experimental periods. Four cows in one Latin square were fitted with ruminal cannulas to allow ruminal and omasal sampling. The dietary treatment factors were CP (14.9 vs. $17.5 \%$; dry matter basis) and RDP (63 vs. $69 \%$ of CP) contents. Dietary RDP concentration was manipulated by including unprocessed or micronized canola meal. Diet adaptation (d 1-20) was followed by $8 \mathrm{~d}$ (d 21-29) of sample and data collection. Continuous intrajugular infusions of $\left[{ }^{15} \mathrm{~N}^{15} \mathrm{~N}\right]$-urea $(220 \mathrm{mg} / \mathrm{d})$ were conducted for $4 \mathrm{~d}(\mathrm{~d}$ 25-29) with concurrent total collections of urine and feces to estimate $\mathrm{N}$ balance and whole-body urea kinetics. Proportions of $\left[{ }^{15} \mathrm{~N}^{15} \mathrm{~N}\right]$ - and $\left[{ }^{14} \mathrm{~N}^{15} \mathrm{~N}\right]$-urea in urinary urea, and ${ }^{15} \mathrm{~N}$ enrichment in feces were used to calculate urea kinetics. For the low-CP diets, cows fed the high-RDP diet had a greater DM intake compared with those fed the low-RDP diet, but the opposite trend was observed for cows fed the high-CP diets. Dietary treatment had no effect on milk yield. Milk composition and milk component yields were largely unaffected by dietary treatment; however, on the low-CP diets, milk fat yield was greater for cows fed the low-RDP diet compared with those fed the high-RDP diet, but it was unaffected by RDP concentration on the high-CP diets. On the high-CP diets, milk urea nitrogen concentration was greater in cows fed the high-RDP diet compared with those fed the low-RDP diet, but it was unaffected
\end{abstract}

Received January 19, 2016.

Accepted April 5, 2016.

${ }^{1}$ Corresponding author: tim.mutsvan@usask.ca by RDP concentration on the low-CP diets. Ruminal $\mathrm{NH}_{3}-\mathrm{N}$ concentration tended to be greater in cows fed the high-CP diet compared with those fed the low-CP diet, and it was greater in cows fed the high-RDP diet as compared with those fed the low-RDP diet. Nitrogen intake and both total $\mathrm{N}$ and urea- $\mathrm{N}$ excretion in urine were greater for cows fed the high-CP diet compared with those fed the low-CP diet. However, $\mathrm{N}$ balance and urinary excretion of purine derivatives were unaffected by dietary treatment. Urea-N entry rate (UER) was greater in cows fed the high-CP diet compared with those fed the low-CP diet; however, UER was unaffected by dietary RDP concentration. The proportion of urea- $\mathrm{N}$ recycled to the gastrointestinal tract (as a percentage of UER) was greater in cows fed the low$\mathrm{CP}$ diet compared with those fed the high-CP diet. In summary, reducing dietary $\mathrm{CP}$ concentration decreased urinary $\mathrm{N}$ excretion but had no effect on milk yield, thus resulting in an overall improvement in milk $\mathrm{N}$ efficiency.

Key words: dairy cow, crude protein, microbial protein, rumen-degradable protein, urea-nitrogen recycling

\section{INTRODUCTION}

The conversion of dietary $\mathrm{N}$ into milk $\mathrm{N}$, which is referred to as milk $\mathrm{N}$ efficiency (MNE), is rather low (typically 20-35\%; Chase et al., 2009). Consequently, 65 to $80 \%$ of dietary $\mathrm{N}$ intake is lost in urine and feces, thus contributing to environmental pollution (Cowling and Galloway 2002; Hristov et al. 2011). As a result, intensive livestock operations like dairy farms are under increasing public pressure to reduce $\mathrm{N}$ excretion so as to improve environmental stewardship. Feeding practices for lactating dairy cows in the United States and Canada have been based on guidelines set by the National Research Council (NRC, 2001), which recommends dietary CP concentrations of 17.5 to $19.0 \%$ to support high levels of milk production. However, feeding such high levels of dietary $\mathrm{CP}$ increases $\mathrm{N}$ excretion while decreasing MNE (Olmos Colmenero and Broderick, 2006); therefore, one approach for decreasing 
$\mathrm{N}$ excretion and improving MNE is to reduce dietary $\mathrm{CP}$ content (Olmos Colmenero and Broderick, 2006). Olmos Colmenero and Broderick (2006) reported that decreasing dietary CP content from 19.4 to $13.5 \%$ decreased urinary $\mathrm{N}$ excretion from 36.2 to $23.8 \%$ (as a proportion of $\mathrm{N}$ intake) and increased MNE from 25.4 to $36.5 \%$. Per unit of feed, protein is a relatively costly nutrient (Chase et al., 2009); therefore, reducing dietary CP could also lower feeding costs for milk production. However, although reducing dietary $\mathrm{CP}$ content can improve $\mathrm{N}$ efficiency and reduce feeding costs, some studies (Cabrita et al., 2011; Lee et al., 2011; Chibisa and Mutsvangwa, 2013) have reported that it can have detrimental effects on milk and milk protein yields, which would be undesirable for economic reasons.

In ruminants, shuttling of $\mathrm{N}$ in the form of $\mathrm{NH}_{3}-\mathrm{N}$ and urea between the portal-drained viscera (particularly the rumen) and the liver, a physiological mechanism referred to as urea- $\mathrm{N}$ salvaging, is important for the conservation of N (Lapierre and Lobley, 2001). Urea-N that is recycled to the rumen can become an important source of $\mathrm{N}$ for microbial growth when RDP supply is limited (Lapierre and Lobley, 2001), and it represents a repartitioning of urea- $\mathrm{N}$ away from urinary excretion toward anabolic use. Enhancing urea-N recycling to the rumen can therefore be a feasible strategy to improve $\mathrm{N}$ efficiency. Many factors regulate urea- $\mathrm{N}$ secretion into the rumen, including ruminal $\mathrm{NH}_{3}-\mathrm{N}$ concentration. Earlier studies indicated that ruminal $\mathrm{NH}_{3}-\mathrm{N}$ concentration was negatively correlated with urea-N transfer into the rumen (Kennedy and Milligan, 1980), although the exact mechanisms for the inhibitory effect of ammonia are still unclear. Egan et al. (1986) proposed that increased $\mathrm{NH}_{3}-\mathrm{N}$ concentration decreased the permeability of the ruminal epithelium to urea- $\mathrm{N}$. Rémond et al. (1996) indicated that urea-N transfer into the rumen was facilitated by bacterial urease activity that maintained a favorable concentration gradient. Because urease activity is negatively correlated with ruminal $\mathrm{NH}_{3}-\mathrm{N}$ concentration (Cheng and Wallace, 1979), decreasing ruminal $\mathrm{NH}_{3}-\mathrm{N}$ concentration should favor urea-N transfer into the rumen. Recently, Lu et al. (2014) confirmed the inhibitory effect of ammonia on urea transfer across ruminal epithelia using a Ussing chamber model and demonstrated that the inhibitory effect was concentration dependent, with saturation at $5 \mathrm{mmol} / \mathrm{L}$. These authors hypothesized that ruminal uptake of ammonia as $\mathrm{NH}_{4}{ }^{+}$at physiological ruminal $\mathrm{pH}(<7)$ resulted in intracellular acidification that reduced the permeability of urea transporters to urea. It is well established that ruminal $\mathrm{NH}_{3}-\mathrm{N}$ concentration is positively correlated with both dietary $\mathrm{N}$ and RDP intakes (Seal and Reynolds, 1993; Reynolds and Kristensen, 2008), so manipulating dietary N and
$\mathrm{RDP}$ intakes can alter urea- $\mathrm{N}$ recycling to the rumen. Decreasing $\mathrm{N}$ intake by feeding low-CP diets increases the proportion of endogenous urea production that is transferred from the bloodstream into the portaldrained viscera (Marini and Van Amburgh, 2003; Wickersham et al., 2008a; Chibisa and Mutsvangwa, 2013). Limited studies have investigated the impacts of altering dietary $\mathrm{RDP}$ concentration on urea- $\mathrm{N}$ transfer to the rumen. Wickersham et al. (2008b) observed that increasing dietary RDP concentration increased urea-N transfer to the gastrointestinal tract (GIT), but RDP concentration had no impact when urea- $\mathrm{N}$ transfer to the GIT was expressed as a proportion of endogenous urea-N production. In that study, however, both RDP concentration and $\mathrm{N}$ intake (which can alter endogenous urea- $\mathrm{N}$ synthesis) increased at the same time so no definitive conclusion could be made about how altering RDP concentration affected urea- $\mathrm{N}$ transfer to the GIT. To our knowledge, no published studies have reported the interactive effects of dietary $\mathrm{CP}$ and $\mathrm{RDP}$ concentrations on urea- $\mathrm{N}$ transfer to the GIT and ruminal microbial protein production in dairy cows that have a high requirement for MP to support high levels of milk production.

Our hypothesis for the present study was that, under feeding conditions that feature reduced dietary $\mathrm{N}$ and $\mathrm{RDP}$ concentrations, urea-N recycling to the GIT will increase to provide $\mathrm{N}$ in support of microbial growth. Therefore, the objective was to determine the interactive effects of dietary $\mathrm{CP}$ and RDP concentrations on urea- $\mathrm{N}$ recycling, $\mathrm{N}$ balance, omasal nutrient flow, and milk production in dairy cows. By providing insufficient dietary RDP to meet microbial $\mathrm{N}$ needs in low-CP diets, it may be possible to increase urea-N recycling to the rumen and maintain microbial protein synthesis that would provide sufficient MP to maintain high levels of milk production that are typically attained with higher-CP diets.

\section{MATERIALS AND METHODS}

Cows used in this study were cared for in accordance with the guidelines of the Canadian Council on Animal Care (1993), and their use was approved by the University of Saskatchewan Animal Care Committee (UCACS Protocol 20040048).

\section{Animals and Experimental Design}

Eight multiparous, lactating Holstein cows (711 \pm $21 \mathrm{~kg}$ of BW; $91 \pm 17$ DIM at the start of the experiment) were used in a replicated $4 \times 4$ Latin square design with a $2 \times 2$ factorial arrangement of dietary treatments. Four cows were surgically fitted with 10.2- 
cm (4-inch) i.d. permanent ruminal cannulas (Bar Diamond, Parma, ID) and were used in a metabolism study to determine dietary effects on urea-N recycling, microbial protein production, ruminal fermentation characteristics, $\mathrm{N}$ balance, and omasal nutrient flow. Each experimental period consisted of $20 \mathrm{~d}$ of dietary adaptation (d 1-20) and $8 \mathrm{~d}$ of sample and data collection (d 21-29). All cows were housed in individual tie-stalls at the Greenbrae Dairy Research Facility (University of Saskatchewan).

\section{Experimental Treatments and Feeding Management}

Experimental treatments were 2 concentrations of dietary CP (14.9 vs. $17.5 \%$; DM basis) and 2 concentrations of RDP (63 vs. $69 \%$ of CP). Dietary RDP concentration was manipulated by the inclusion of unprocessed or micronized canola meal. Canola meal was micronized at 160 to $165^{\circ} \mathrm{C}$ and was held at that temperature for $20 \mathrm{~min}$ in an insulated container (InfraReady Products Ltd., Saskatoon, SK, Canada). A single batch of solvent-extracted canola meal was purchased from one source (Cargill Ltd., Clavet, SK, Canada) and was then split into unprocessed and micronized canola meal for use in this experiment. The chemical compositions of the major feed ingredients that were used to make experimental diets are presented in Table 1. Experimental diets were composed of a 50:50 forage to concentrate ratio (on a DM basis) and were fed to cows as TMR twice daily at 0900 and $1700 \mathrm{~h}$ for ad libitum intake. The forage portion of the diet consisted of barley silage ( $70 \%$ on a DM basis) and chopped alfalfa hay $(30 \%$ on a DM basis). The ingredient and chemical compositions of experimental diets are presented in Table 2.

\section{Sample Collection}

During each experimental period, individual cow feed intake was recorded daily. Samples of TMR and orts were collected on 3 consecutive days (d 27-29) and were stored at $-20^{\circ} \mathrm{C}$ pending chemical analysis. Cows were milked 3 times daily at 0430, 1230, and $1900 \mathrm{~h}$, and milk weights were recorded. Milk samples were collected on 3 consecutive days (d 27-29) from all 3 milkings into vials containing 2-bromo-2-nitropropane1-2-diol as a preservative. For each cow, daily milk samples were composited proportionally based on milk yield and submitted to the CanWest DHI Milk Testing Laboratory (Edmonton, AB, Canada) for analysis.

Omasal digesta flow was determined using indigestible NDF (iNDF; Reynal et al., 2005), Yb (administered as $\mathrm{YbCl}_{3}$; Siddons et al., 1985), and Cr (administered as Cr-EDTA; Udén et al., 1980) as markers for the large particle $(\mathbf{L P})$, small particle (SP), and fluid (FP) phases, respectively. Just before marker infusions into the rumen were initiated on d 15, samples of whole ruminal contents and whole omasal digesta were taken from each cow to determine background concentrations of $\mathrm{Cr}$ and $\mathrm{Yb}$. At the beginning of marker infusions, priming doses equal to one-half of the daily dose of $\mathrm{Yb}$ and $\mathrm{Cr}$ were administered via the ruminal cannula. Thereafter, between d 15 and d 23, marker solutions prepared in distilled water and containing $\mathrm{Yb}(2.2$ $\mathrm{g} / \mathrm{d})$ and $\mathrm{Cr}(2.7 \mathrm{~g} / \mathrm{d})$ were then continuously infused into the rumen at a constant rate of $1 \mathrm{~L} / \mathrm{d}$ using a peristaltic pump (Watson and Marlow, Cornwall, UK; model 205U). The omasal sampling technique as described by Huhtanen et al. (1997) was used to collect omasal digesta. Omasal digesta samples $(300 \mathrm{~mL}$ per sampling) were collected every $6 \mathrm{~h}$ at 0900,1500 , and $2100 \mathrm{~h}$ on $\mathrm{d} 21 ; 0300,1200,1800$, and $2400 \mathrm{~h}$ on $\mathrm{d}$ 22 ; and $0600 \mathrm{~h}$ on $\mathrm{d} 23$ to represent a 24-h feeding cycle. Omasal digesta samples were pooled for each cow in each period to yield a 2.4-L composite sample that was stored at $-20^{\circ} \mathrm{C}$ pending chemical analysis. At the same time points as for omasal sampling, 1,000 $\mathrm{mL}$ of ruminal contents was collected by manually taking $250 \mathrm{~mL}$ from the cranial-ventral, caudal-ventral, central, and cranial-dorsal regions through the ruminal cannula. Ruminal contents were mixed thoroughly and

Table 1. Chemical composition of dietary ingredients $(\mathrm{n}=4$ samples per ingredient)

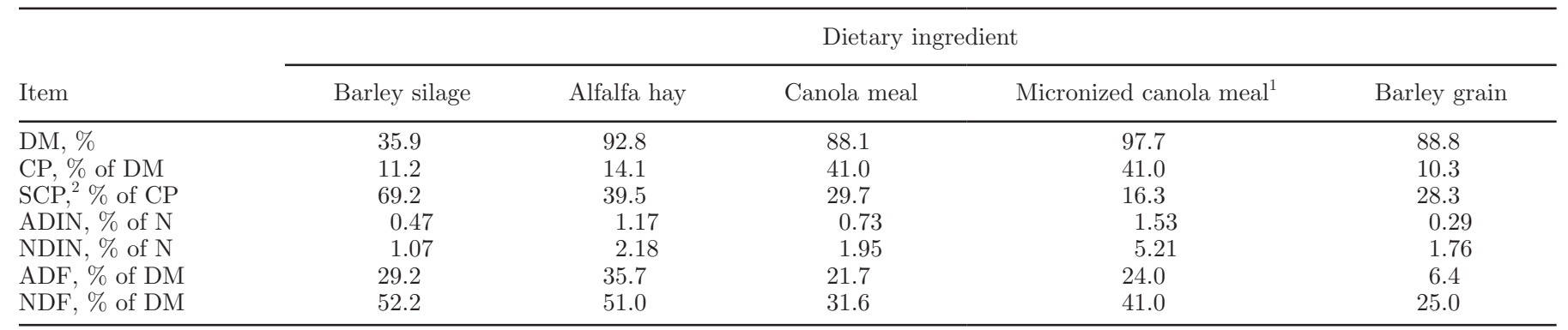

${ }^{1}$ Canola meal micronized at 160 to $165^{\circ} \mathrm{C}$ and held at that temperature for 20 min.

${ }^{2} \mathrm{SCP}=$ soluble crude protein. 
Table 2. Ingredient and chemical composition of experimental diets fed to dairy cows

\begin{tabular}{|c|c|c|c|c|}
\hline \multirow[b]{2}{*}{ Item } & \multicolumn{2}{|c|}{ Low CP } & \multicolumn{2}{|c|}{ High CP } \\
\hline & Low RDP & High RDP & Low RDP & High RDP \\
\hline \multicolumn{5}{|c|}{ Ingredient composition, $\%$ of diet DM } \\
\hline Barley silage & 34.6 & 34.6 & 34.4 & 34.4 \\
\hline Alfalfa hay & 14.6 & 14.6 & 14.5 & 14.5 \\
\hline Barley grain (rolled) & 38.3 & 38.3 & 30.8 & 30.8 \\
\hline Canola meal & 0.0 & 10.2 & 0.0 & 18.1 \\
\hline Micronized canola meal & 10.2 & 0.0 & 18.1 & 0.0 \\
\hline Mineral-vitamin $\operatorname{mix}^{1}$ & 1.6 & 1.6 & 1.5 & 1.5 \\
\hline Dynamate $^{2}$ & 0.1 & 0.1 & 0.1 & 0.1 \\
\hline Limestone & 0.4 & 0.4 & 0.4 & 0.4 \\
\hline Sodium bicarbonate & 0.3 & 0.3 & 0.3 & 0.3 \\
\hline \multicolumn{5}{|l|}{ Chemical composition } \\
\hline DM, \% & 46.3 & 46.5 & 45.4 & 46.8 \\
\hline OM, \% of DM & 92.0 & 92.0 & 91.2 & 91.5 \\
\hline $\mathrm{CP}, \%$ of $\mathrm{DM}$ & 14.9 & 14.9 & 17.5 & 17.5 \\
\hline $\mathrm{RDP}^{3} \%$ of $\mathrm{CP}$ & 65.1 & 69.8 & 61.0 & 68.0 \\
\hline ADIN, \% of $\mathrm{N}$ & 1.8 & 1.1 & 2.6 & 1.6 \\
\hline NDIN, \% of $\mathrm{N}$ & 2.3 & 1.4 & 2.9 & 1.4 \\
\hline Ether extract, $\%$ of DM & 2.6 & 2.5 & 2.8 & 2.6 \\
\hline $\mathrm{ADF}, \%$ of $\mathrm{DM}$ & 22.9 & 21.8 & 25.3 & 24.2 \\
\hline $\mathrm{NDF}, \%$ of $\mathrm{DM}$ & 36.3 & 35.6 & 38.6 & 37.0 \\
\hline $\mathrm{NE}_{\mathrm{L}},{ }^{3} \mathrm{Mcal} / \mathrm{kg}$ & 1.48 & 1.45 & 1.50 & 1.49 \\
\hline
\end{tabular}

${ }^{1}$ Contained (per kilogram of premix; DM basis): $16.0 \% \mathrm{Ca}, 8.0 \% \mathrm{P}, 4.5 \% \mathrm{Mg}, 1.8 \% \mathrm{~K}, 1.0 \% \mathrm{~S}, 6.3 \% \mathrm{Na}, 10 \%$ $\mathrm{Cl}, 2,100 \mathrm{mg}$ of $\mathrm{Fe}, 2,160 \mathrm{mg}$ of $\mathrm{Zn}, 675 \mathrm{mg}$ of $\mathrm{Cu}, 1,120 \mathrm{mg}$ of $\mathrm{Mn}, 17 \mathrm{mg}$ of Se, $16 \mathrm{mg}$ of Co, $40 \mathrm{mg}$ of I, $240,000 \mathrm{IU}$ of vitamin A, 50,000 IU of vitamin D, and 1,500 IU of vitamin E.

${ }^{2}$ Dynamate (Eastern Minerals Inc., Henderson, NC) contained $18 \% \mathrm{~K}, 11 \% \mathrm{Mg}$, and $22 \% \mathrm{~S}$.

${ }^{3}$ Estimated using CPM-Dairy (v 3.0.8, Cornell University, Ithaca, NY; University of Pennsylvania, Kennett Square, PA; William H. Miner Agricultural Research Institute, Chazy, NY) using the chemical analysis of feed ingredients.

strained through 4 layers of cheesecloth. Ruminal fluid $\mathrm{pH}$ was immediately determined using a Model 265A portal pH meter (Orion Research Inc., Beverly, MA). A 5-mL aliquot of ruminal fluid was preserved with 1 $\mathrm{mL}$ of $\mathrm{H}_{2} \mathrm{PO}_{4}(25 \% \mathrm{wt} / \mathrm{vol})$ and stored at $-20^{\circ} \mathrm{C}$ for later analysis of ruminal short-chain fatty acid (SCFA) concentrations. A second 5-mL aliquot was preserved with $1 \mathrm{~mL}$ of $1 \% \mathrm{H}_{2} \mathrm{SO}_{4}$ and stored at $-20^{\circ} \mathrm{C}$ for later analysis of ruminal $\mathrm{NH}_{3}-\mathrm{N}$ concentrations. A third 15$\mathrm{mL}$ aliquot was not acidified and was stored at $-20^{\circ} \mathrm{C}$ for the determination of osmolarity.

On d 24, ruminally cannulated cows were fitted with temporary vinyl catheters $(0.86 \mathrm{~mm}$ i.d. $\times 1.32 \mathrm{~mm}$ o.d.; Scientific Commodities Inc., Lake Havasu City, $\mathrm{AZ}$ ) in both the right and left jugular veins to facilitate isotope infusion and blood sampling. Urea- $\mathrm{N}$ transfer to the GIT and N balance were then determined from $\mathrm{d} 25$ to 29 using procedures described by Lobley et al. (2000). Briefly, samples of urine and feces were collected on d 25 (before the initiation of $\left[{ }^{15} \mathrm{~N}^{15} \mathrm{~N}\right]$-urea infusions) to measure ${ }^{15} \mathrm{~N}$ natural abundance. Starting at $0800 \mathrm{~h}$ on d 25, $\left[{ }^{15} \mathrm{~N}^{15} \mathrm{~N}\right]$-urea (99.8 atom percent ${ }^{15} \mathrm{~N}$; Cambridge Isotope Laboratories, Tewksbury, MA) dissolved in $0.15 M$ sterile saline solution was continuously infused for $96 \mathrm{~h}$ into a jugular vein at a rate of $220 \mathrm{mg} / \mathrm{d}$ using a peristaltic pump (Watson and Marlow; model 205U).
Total fecal and urine outputs were collected daily for 4 d (d 25-29). Total daily fecal output for each cow was collected into large steel trays that were placed in the gutter behind each stall. Feces were mixed thoroughly, quantitatively transferred into a plastic container, and weighed. A $5 \%$ aliquot was taken daily for each cow and stored at $-20^{\circ} \mathrm{C}$. Total urine collections were facilitated using indwelling Bardex Foley bladder catheters (26 Fr, 75-mL ribbed balloon, lubricious-coated; C. R. Bard Inc., Covington, GA). Bladder catheters were inserted on d 24 before connection to urine collection tubing at the initiation of intrajugular $\left[{ }^{15} \mathrm{~N}^{15} \mathrm{~N}\right]$-urea infusions on $\mathrm{d} 25$. Urine was collected into $20-\mathrm{L}$ polyethylene Carboy containers that contained $200 \mathrm{~mL}$ of concentrated $\mathrm{HCl}$ (VWR Scientific, Mississauga, ON, Canada) to maintain urine at a $\mathrm{pH}<3$. The acidification of urine during collection was necessary to prevent microbial growth and volatilization of $\mathrm{NH}_{3}-\mathrm{N}$. Total daily urine output for each cow was weighed and mixed thoroughly, and then a $5 \%$ aliquot was collected. Daily urine subsamples were composited by cow in each period and stored at $-20^{\circ} \mathrm{C}$. Also, a $50-\mathrm{mL}$ subsample of urine was collected daily and stored at $-20^{\circ} \mathrm{C}$ for later analysis of $\left[{ }^{15} \mathrm{~N}^{15} \mathrm{~N}\right]-$ and $\left[{ }^{14} \mathrm{~N}^{15} \mathrm{~N}\right]$-urea enrichment. In addition, a 2-mL urine subsample was collected daily, diluted with $8 \mathrm{~mL}$ of distilled water and stored at $-20^{\circ} \mathrm{C}$ for later analysis of 
purine derivatives (i.e., uric acid plus allantoin). During total urine and fecal collections, cows were milked in their tie-stalls so that total collections and isotopic infusions would not be interrupted.

\section{Sample Analyses}

Composited milk samples were analyzed for CP, fat, lactose, and MUN concentrations using an infrared analyzer (Milko Scan FT 6000, Foss Electric, Hillerød, Denmark; AOAC International, 2002; method 972.16). Frozen TMR, orts, and fecal samples were thawed overnight at room temperature and analyzed for DM by drying in an oven at $60^{\circ} \mathrm{C}$ for $48 \mathrm{~h}(\mathrm{AOAC}, 1990)$. Dried TMR, orts, and fecal samples were then ground through a 1-mm screen using a Christy-Norris mill (Christy and Norris Ltd., Chelmsford, UK) and pooled by cow for each experimental period. Pooled samples were analyzed for $\mathrm{OM}$ by ashing at $600^{\circ} \mathrm{C}$ for at least 8 h (AOAC, 1990; method 942.05), ether extract (AOAC, 1990; method 920.39), CP using the macro-Kjeldahl procedure (AOAC, 1990; method 984.13), soluble CP (Roe et al., 1990), and ADF and NDF (Van Soest et al., 1991). Heat-stable $\alpha$-amylase and sodium sulfite were used for NDF determination. The TMR samples were also analyzed for ADIN and NDIN (Licitra et al., 1996). Sodium sulfite was not used for NDIN determination because its use is not recommended (Licitra et al., 1996).

The composited omasal digesta samples were thawed at room temperature and separated into LP, SP, and FP phases using procedures described by Reynal et al. (2005). The separated LP, SP and FP phases were then freeze-dried and ground through a $1-\mathrm{mm}$ screen using a Christy-Norris mill. To determine $\mathrm{Cr}$ and $\mathrm{Yb}$ concentrations, a 1-g subsample of the LP, SP, and FP samples was combusted at $550^{\circ} \mathrm{C}$ for $8 \mathrm{~h}$ in a muffle furnace (AOAC, 1990) before nitric acid digestion as described by Vicente et al. (2004). Subsequently, Cr concentration was measured by atomic absorption spectrophotometry (Perkin Elmer 2300, Perkin-Elmer Corp., Norwalk, CT), whereas Yb concentration was measured by atomic emission spectroscopy (Varian Spectra 220, Varian, Mulgrave, Australia). Indigestible NDF was determined on pooled experimental TMR (3-g subsample), LP (1.5-g subsample), and SP (3.5-g subsample) by ruminal incubation of subsamples (in triplicate for TMR, LP, and SP) in 5- $\times 10-\mathrm{cm}$ nylon mesh bags (6- $\mu \mathrm{m}$ pore size; part no. 03-6/5, Sefar America Inc., Depew, NY) for 12 d (Ahvenjarvi et al., 2000). Three ruminally cannulated cows were used for iNDF determination. After removal from the rumen, the nylon mesh bags were rinsed in water for $30 \mathrm{~min}$ before NDF analysis. The concentrations of $\mathrm{Cr}, \mathrm{Yb}$, and
iNDF in the LP and SP phases and $\mathrm{Cr}$ and $\mathrm{Yb}$ concentrations in the FP phase were used to reconstitute the omasal true digesta (OTD) flowing out of the rumen according to the triple marker method as described by France and Siddons (1986). To determine the omasal flow of nutrients, the reconstituted OTD samples were analyzed for $\mathrm{OM}, \mathrm{N}, \mathrm{ADF}$, and NDF using procedures described previously.

For each experimental period, background fecal samples and fecal samples that were collected on a daily basis during total collections were thawed overnight at room temperature before DM analysis (AOAC, 1990; method 930.15). Dried fecal samples were then ground through a 1-mm screen using a Christy-Norris mill before being finely ground using a ball mill. Thereafter, fecal subsamples containing approximately $100 \mu \mathrm{g}$ of $\mathrm{N}$ were weighed into $5-\times 9$-mm tin capsules (Elemental Microanalysis Limited, Okehampton, UK). To volatilize $\mathrm{NH}_{3}-\mathrm{N}, 50 \mu \mathrm{L}$ of $72 \mathrm{mM} \mathrm{K} \mathrm{CO}_{3}$ was added to each tin capsule followed by incubation in a forced-air oven at $60^{\circ} \mathrm{C}$ for $24 \mathrm{~h}$ (Reynal et al., 2005). Enrichment of ${ }^{15} \mathrm{~N}$ in fecal subsamples was then measured by combustion to $\mathrm{N}_{2}$ gas in an elemental analyzer and continuous flow isotope ratio-mass spectrometry (Lobley et al., 2000).

Urinary urea-N was determined using the diacetyl monoxime method (Procedure No. 0580, Stanbio Laboratory, Boerne, TX) on background urine samples and the 50-mL urine subsamples that were collected daily (d 25-29). Urinary urea was then isolated by applying urine containing approximately $1.5 \mathrm{mg}$ of urea-N to a prepacked cation exchange resin column (AG-50W- $\times$ 8 resin, 100-200 mesh, $\mathrm{H}^{+}$form; BioRad Laboratories, Richmond, CA) as described by Archibeque et al. (2001). Previous studies determined that isolation of approximately $1.5 \mathrm{mg}$ of urea $\mathrm{N}$ was suitable to ensure sufficient amounts of gas for $\left[{ }^{15} \mathrm{~N}^{15} \mathrm{~N}\right]$ - and $\left[{ }^{14} \mathrm{~N}^{15} \mathrm{~N}\right]$-urea enrichment analysis, while minimizing the occurrence of non-monomolecular degradation of urea (Archibeque et al., 2001; Marini and Van Amburgh, 2003). After the application of the desired volume of urine, resins were then washed with $7 \mathrm{~mL}$ of $\mathrm{N}$-free water before elution of urea- $\mathrm{N}$ into test tubes with $20 \mathrm{~mL}$ of $\mathrm{N}$-free water. Following air-drying of the eluate at $60^{\circ} \mathrm{C}$, three $1-\mathrm{mL}$ rinses of $\mathrm{N}$-free water were used to quantitatively transfer urea- $\mathrm{N}$ from the test tubes into $17-\times 60-\mathrm{mm}$ borosilicate glass tubes. Urea- $\mathrm{N}$ samples were then freeze-dried and analyzed for $\left[{ }^{15} \mathrm{~N}^{15} \mathrm{~N}\right]$ - and $\left[{ }^{14} \mathrm{~N}^{15} \mathrm{~N}\right]$-urea enrichment by isotope ratio-mass spectrometry $\left({ }^{15} \mathrm{~N}\right.$ Analysis Laboratory, University of Illinois at Urbana-Champaign) as described by Lobley et al. (2000). Standards prepared using $\left[{ }^{15} \mathrm{~N}^{15} \mathrm{~N}\right]$-urea $\left(99.8\right.$ atom $\left.\%{ }^{15} \mathrm{~N}\right)$ and $\left[{ }^{14} \mathrm{~N}^{14} \mathrm{~N}\right]$-urea (natural abundance urea; 0.364 atom $\%{ }^{15} \mathrm{~N}$ ) were also analyzed, and results were used to correct for $\left[{ }^{14} \mathrm{~N}^{15} \mathrm{~N}\right]$ urea produced during non-monomolecular reactions 
(Lobley et al., 2000). Total $\mathrm{N}$ in samples of composited urine samples was determined using the macro-Kjeldahl procedure (AOAC, 1990; method 976.05). Diluted daily urine samples (collected on d 25-29) were composited by cow for each period (proportionally based on daily urine output) and analyzed for uric acid (Fossati et al., 1980) and allantoin (Chen and Gomes, 1992).

Frozen ruminal fluid samples were thawed at room temperature and then centrifuged at $20,000 \times g$ for 15 min at $4^{\circ} \mathrm{C}$ to obtain a clear supernatant. The supernatants from ruminal fluid samples that had been preserved with $25 \% \mathrm{H}_{2} \mathrm{PO}_{4}$ were filtered through a 0.45$\mu \mathrm{m}$ membrane. Subsequently, a $0.9-\mathrm{mL}$ portion of the filtered supernatant was mixed with $0.1 \mathrm{~mL}$ of $10 \mathrm{mg} /$ $\mathrm{mL}$ crotonic acid, which was used as an internal standard. Thereafter, ruminal SCFA concentrations were determined by gas chromatography (Erwin et al., 1961) using an Agilent 6890 Series Gas Chromatography system (Wilmington, DE). The supernatants of ruminal fluid samples that had been preserved with $\mathrm{H}_{2} \mathrm{SO}_{4}$ were analyzed for $\mathrm{NH}_{3}-\mathrm{N}$ concentration using a phenol-hypochlorite assay (Broderick and Kang, 1980). Osmolality was measured on nonacidified ruminal fluid samples using a Vapro Vapor Pressure Osmometer (model 5520; Wescor Inc., Logan, UT).

\section{Calculations and Statistical Analysis}

Urea-N kinetics were calculated using urinary enrichment of $\left[{ }^{15} \mathrm{~N}^{15} \mathrm{~N}\right]$ - and $\left[{ }^{14} \mathrm{~N}^{15} \mathrm{~N}\right]$-urea, and total ${ }^{15} \mathrm{~N}$ excretion in feces according to Lobley et al. (2000). Based on this model, a fraction of urea- $\mathrm{N}$ synthesized in the liver (urea-N entry rate, UER) is irreversibly lost in urine (urinary urea-N elimination, UUE), whereas the remaining fraction is recycled to the GIT (GIT entry rate, GER). Urea-N recycled to the GIT is hydrolyzed by bacterial urease to $\mathrm{NH}_{3}-\mathrm{N}$, which has 3 fates: (1) excretion in feces (urea-N in feces, UFE); (2) reabsorption into portal blood and re-entry into the ornithine cycle (ROC), resulting in the formation of 3 urea- $\mathrm{N}$ species (i.e., $\left[{ }^{14} \mathrm{~N}^{14} \mathrm{~N}\right]-,\left[{ }^{14} \mathrm{~N}^{15} \mathrm{~N}\right]$-, and $\left[{ }^{15} \mathrm{~N}^{15} \mathrm{~N}\right]$-urea); or (3) utilization for anabolic purposes (UUA), which is assumed to be primarily ruminal microbial protein synthesis (Lobley et al., 2000). According to the model, UUA is calculated as the difference between GER and (ROC + UFE). Apparent ruminal nutrient digestibilities were calculated as the nutrient intake minus the omasal flow of nutrient, with flows expressed as kilograms per day (Reynal and Broderick, 2005).

Data on ruminal fermentation characteristics $(\mathrm{pH}$, osmolality, and $\mathrm{NH}_{3}-\mathrm{N}$ and SCFA concentrations), nutrient digestion, omasal nutrient flow, and urea-N kinetics ( $\mathrm{n}=4$ cows) were analyzed as a $4 \times 4$ Latin square using the Proc Mixed procedure of SAS Insti- tute (2004; version 9.1, SAS Institute Inc., Cary, NC). All production data (i.e., DM intakes, milk production and composition, and milk component yields; $\mathrm{n}=8$ cows) were analyzed as replicated $4 \times 4$ Latin square design using the Proc Mixed procedure of SAS. For this analysis, the statistical models included the following independent variables: cow, period, dietary $\mathrm{CP}$ content, dietary RDP content, and the dietary $\mathrm{CP}$ content $\times$ dietary RDP content interaction. Period and dietary treatment were considered as fixed, whereas cow was considered as random. Because ruminal fermentation characteristics had repeated measurements, the repeated measures option within the PROC MIXED procedure of SAS Institute (2004) was used to analyze that data. Treatment differences were considered significant when $P \leq 0.05$ and tendencies when $0.05<P \leq 0.10$.

\section{RESULTS}

\section{Dietary Characteristics}

Chemical composition of dietary ingredients is presented in Table 1. As expected, soluble CP content was lower in diets containing micronized canola meal compared with those containing unprocessed canola meal. Also, micronized canola meal had greater ADIN and NDIN contents than unprocessed canola meal. Experimental TMR were formulated to contain 15.0 or $17.5 \% \mathrm{CP}$, and TMR chemical composition (Table 2) indicates that the targeted CP contents were achieved. Target dietary RDP contents were 61 and 69\% (as percentage of $\mathrm{CP}$ ) and calculated RDP contents (from the Cornell-Penn-Miner Dairy System; CPM Version 3.0.8; published jointly by Cornell University, Ithaca, NY; University of Pennsylvania, Philadelphia, PA; and Miner Institute, Chazy, NY) using dietary ingredient composition; Table 2) indicated that these RDP contents were achieved, except for the low-CP-low-RDP diet, which had an RDP content of $65.1 \%$ rather than the desired $61 \%$.

\section{Ruminal Fermentation Characteristics}

Daily average ruminal $\mathrm{pH}$ was unaffected by dietary treatment (Table 3). Ruminal $\mathrm{NH}_{3}-\mathrm{N}$ concentration (mean $\pm \mathrm{SEM})$ tended $(P=0.06)$ to be greater in cows fed the high-CP diet compared with those fed the low-CP diet $(20.3 \pm 1.02$ vs. $17.4 \pm 1.02 \mathrm{mg} / \mathrm{dL})$ and was greater $(P<0.01)$ in cows fed the high-RDP diet compared with those fed the low-RDP $\operatorname{diet}(21.5 \pm 1.04$ vs. $16.2 \pm 1.04 \mathrm{mg} / \mathrm{dL}$ ). Ruminal osmolality was unaffected by dietary treatment. Individual SCFA and total SCFA concentrations and acetate:propionate ratios were largely unaffected by dietary treatment; however, 
Table 3. Ruminal fermentation characteristics in dairy cows $(\mathrm{n}=4)$ fed diets with low or high $\mathrm{CP}$ concentrations and containing low or high $\mathrm{RDP}$ concentrations

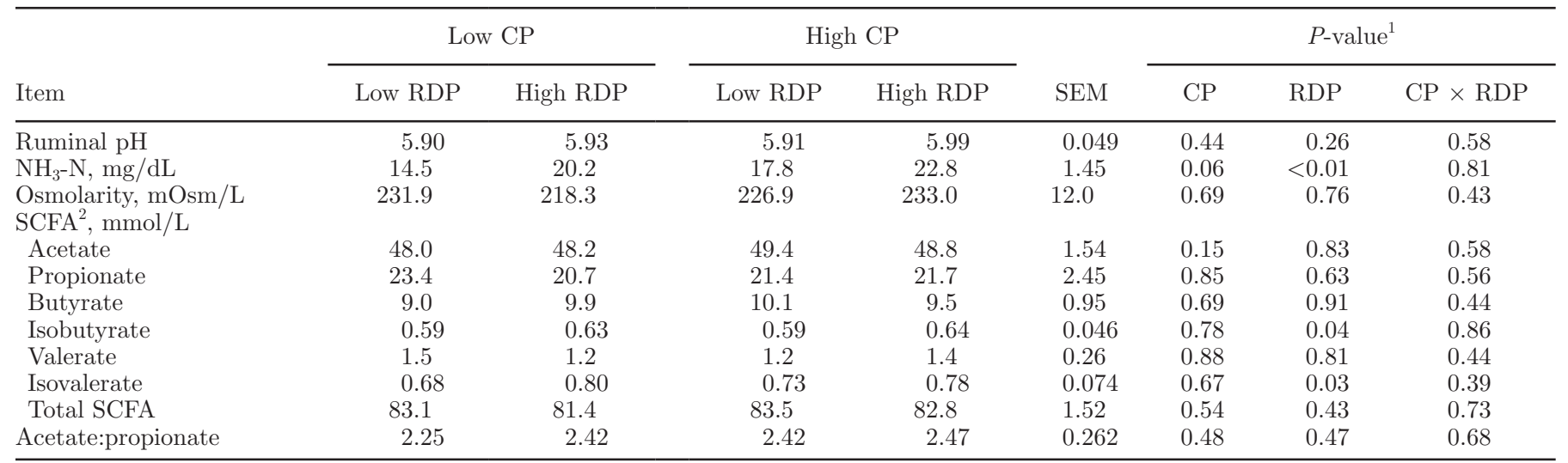

${ }^{1} \mathrm{CP}=$ effect of dietary $\mathrm{CP}$ concentration; RDP $=$ effect of dietary RDP concentration; $\mathrm{CP} \times \mathrm{RDP}=$ interaction.

${ }^{2} \mathrm{SCFA}=$ short-chain fatty acids.

ruminal concentrations of isobutyrate and isovalerate were greater $(P<0.05)$ in cows fed the high-RDP diet compared with those fed the low-RDP diet.

\section{Nutrient Intake, Omasal Nutrient Flow, and Ruminal and Total-Tract Nutrient Digestibility}

For the low-CP diets, cows fed the high-RDP diet had a greater DM intake compared with those fed the low-RDP diet, but the opposite trend was observed for cows fed the high-CP diets (interaction, $P=0.03$; Table 4). On the low-CP diet, both DM $(P \leq 0.02)$ and $\mathrm{OM}(P \leq 0.03)$ digested in the rumen [expressed in absolute amounts (kilograms per day) or as a proportion of intake] were greater in cows fed the highRDP diet as compared with those fed the low-RDP diet, but no differences in DM and OM digested in the rumen were observed between cows fed the low- and high-RDP diets on the high-CP diet (interaction; Table 4 ). Total-tract DM and OM digestibilities were unaffected by dietary treatment. Organic matter flow at the omasum was greater $(P<0.05)$ for cows fed the high-CP diet compared with those fed the low-CP diet, but was unaffected by dietary RDP concentration. For the low-CP diets, cows fed the high-RDP diet had a greater NDF intake compared with those fed the low$\mathrm{RDP}$ diet, but the opposite trend was observed for cows fed the high-CP diets (interaction, $P=0.02$ ). Also, for the low-CP diets, cows fed the high-RDP diet tended to have a greater DM intake compared with those fed the low-RDP diet, but the opposite trend was observed for cows fed the high-CP diets (tendency for interaction, $P=0.07)$. Both NDF $(4.1 \pm 0.18$ vs. $3.3 \pm 0.18 \mathrm{~kg} / \mathrm{d}$; $P<0.01)$ and $\operatorname{ADF}(2.15 \pm 0.091$ vs. $1.65 \pm 0.091$ $\mathrm{kg} / \mathrm{d} ; P<0.01)$ flows at the omasum were greater in cows fed the high-CP diet compared with those fed the
low-CP diet. Both NDF $(P \leq 0.03)$ and $\operatorname{ADF}(P \leq$ 0.01 ) apparently digested in the rumen (expressed in absolute amounts or as a percentage of nutrient intake), and NDF $(P<0.01)$ and $\operatorname{ADF}(P<0.01)$ total-tract digestibilities were greater in cows fed the low-CP diet compared with those fed the high-CP diet.

\section{Nitrogen Balance and Urinary Purine Derivative Excretion}

Nitrogen intake $(625.9 \pm 19.21$ vs. $735.7 \pm 19.21 \mathrm{~g} / \mathrm{d}$; $P<0.01)$ and urinary excretion of total N $(161.3 \pm$ 11.32 vs. $256.2 \pm 11.32 \mathrm{~g} / \mathrm{d} ; P<0.01)$ and urea-N $(137.9 \pm 9.24$ vs. $197.4 \pm 9.24 \mathrm{~g} / \mathrm{d} ; P<0.01)$ were lower in cows fed the low-CP diet compared with those fed the high-CP diet (Table 5). Urine output tended to be lower $(P=0.06)$ in cows fed the low-CP diet compared with those fed the high-CP diet. On the high-CP diet, fecal $\mathrm{N}$ excretion was greater in cows fed the low-RDP diet compared with those fed the high-RDP diet, but no difference in fecal $\mathrm{N}$ excretion was observed between cows fed the low- and high-RDP contents with the low-CP diets (interaction, $P<0.01$ ). Milk $\mathrm{N}$ output, $\mathrm{N}$ retention, and $\mathrm{N}$ digestibility were not affected by dietary treatment; however, MNE (calculated as milk $\mathrm{N} / \mathrm{N}$ intake $\times 100)$ was greater $(P<0.01)$ for cows fed the low-CP diet compared with those fed the high-CP diet. Urinary excretion of uric acid, allantoin, and total purine derivative excretion were unaffected by dietary treatment (Table 5).

\section{Urea-N Kinetics}

Endogenous urea-N synthesis (i.e., UER) was greater $(498.6 \pm 18.63$ vs. $420.8 \pm 18.63 \mathrm{~g} / \mathrm{d} ; P<0.01)$ in cows fed the high-CP diet compared with those fed the low- 
Table 4. Dry matter intake, ruminal and total-tract nutrient digestibility, and omasal nutrient flow in dairy cows $(\mathrm{n}=4)$ fed diets with low or high CP concentrations and containing low or high RDP concentrations

\begin{tabular}{|c|c|c|c|c|c|c|c|c|}
\hline \multirow[b]{2}{*}{ Item } & \multicolumn{2}{|c|}{ Low CP } & \multicolumn{2}{|c|}{ High CP } & \multirow[b]{2}{*}{ SEM } & \multicolumn{3}{|c|}{$P$-value ${ }^{1}$} \\
\hline & Low RDP & High RDP & Low RDP & High RDP & & $\mathrm{CP}$ & $\mathrm{RDP}$ & $\mathrm{CP} \times \mathrm{RDP}$ \\
\hline Intake, kg/d & $25.5^{\mathrm{b}}$ & $27.0^{\mathrm{ab}}$ & $27.0^{\mathrm{a}}$ & $25.2^{\mathrm{b}}$ & 0.80 & 0.83 & 0.77 & 0.03 \\
\hline Omasal flow, kg/d & 15.0 & 13.8 & 15.1 & 15.5 & 0.91 & 0.13 & 0.40 & 0.16 \\
\hline \multicolumn{9}{|l|}{ Digested in the rumen } \\
\hline $\mathrm{kg} / \mathrm{d}$ & $10.4^{\mathrm{b}}$ & $13.0^{\mathrm{a}}$ & $11.8^{\mathrm{ab}}$ & $10.0^{\mathrm{b}}$ & 0.72 & 0.23 & 0.53 & 0.01 \\
\hline \multicolumn{9}{|l|}{$\mathrm{OM}$} \\
\hline Intake, $\mathrm{kg} / \mathrm{d}$ & 23.2 & 24.7 & 24.8 & 23.3 & 0.67 & 0.85 & 0.99 & 0.05 \\
\hline Omasal flow, kg/d & 11.5 & 10.9 & 12.0 & 12.2 & 0.65 & 0.03 & 0.52 & 0.28 \\
\hline \multicolumn{9}{|l|}{ Digested in the rumen } \\
\hline $\mathrm{kg} / \mathrm{d}$ & $11.9^{\mathrm{b}}$ & $13.7^{\mathrm{a}}$ & $12.7^{\mathrm{ab}}$ & $11.2^{\mathrm{b}}$ & 0.59 & 0.16 & 0.76 & 0.02 \\
\hline$\%$ of OM intake & $50.9^{\mathrm{ab}}$ & $55.6^{\mathrm{a}}$ & $51.7^{\mathrm{ab}}$ & $47.6^{\mathrm{b}}$ & 2.08 & 0.05 & 0.83 & 0.03 \\
\hline Total-tract digestibility, \% & 71.6 & 70.1 & 70.4 & 70.1 & 1.17 & 0.61 & 0.45 & 0.61 \\
\hline \multicolumn{9}{|l|}{ Digested in the rumen } \\
\hline$\%$ of NDF intake & 64.9 & 67.4 & 56.3 & 58.0 & 3.01 & 0.01 & 0.42 & 0.88 \\
\hline Total-tract digestibility, $\%$ & 68.9 & 68.3 & 66.1 & 64.8 & 1.18 & $<0.01$ & 0.30 & 0.74 \\
\hline \multicolumn{9}{|l|}{$\mathrm{ADF}$} \\
\hline Intake, kg/d & 6.1 & 6.3 & 6.2 & 5.9 & 0.34 & 0.23 & 0.63 & 0.07 \\
\hline Omasal flow, $\mathrm{kg} / \mathrm{d}$ & 1.6 & 1.7 & 2.2 & 2.1 & 0.13 & $<0.01$ & 0.87 & 0.13 \\
\hline \multicolumn{9}{|l|}{ Digested in the rumen } \\
\hline $\mathrm{kg} / \mathrm{d}$ & 4.5 & 4.6 & 4.1 & 3.9 & 0.33 & 0.01 & 0.83 & 0.31 \\
\hline$\%$ of $\mathrm{ADF}$ intake & 72.7 & 72.8 & 65.3 & 65.3 & 2.36 & $<0.01$ & 0.96 & 0.97 \\
\hline
\end{tabular}

${ }^{\mathrm{a}, \mathrm{b}}$ Means within a row with different superscripts differ $(P<0.05)$.

${ }^{1} \mathrm{CP}=$ effect of dietary $\mathrm{CP}$ concentration; $\mathrm{RDP}=$ effect of dietary RDP concentration; $\mathrm{CP} \times \mathrm{RDP}=$ interaction.

Table 5. Nitrogen $(\mathrm{N})$ balance, total-tract $\mathrm{N}$ digestibility, and urinary purine derivative excretion in dairy cows $(\mathrm{n}=4)$ fed diets with low or high CP concentrations and containing low or high RDP concentrations

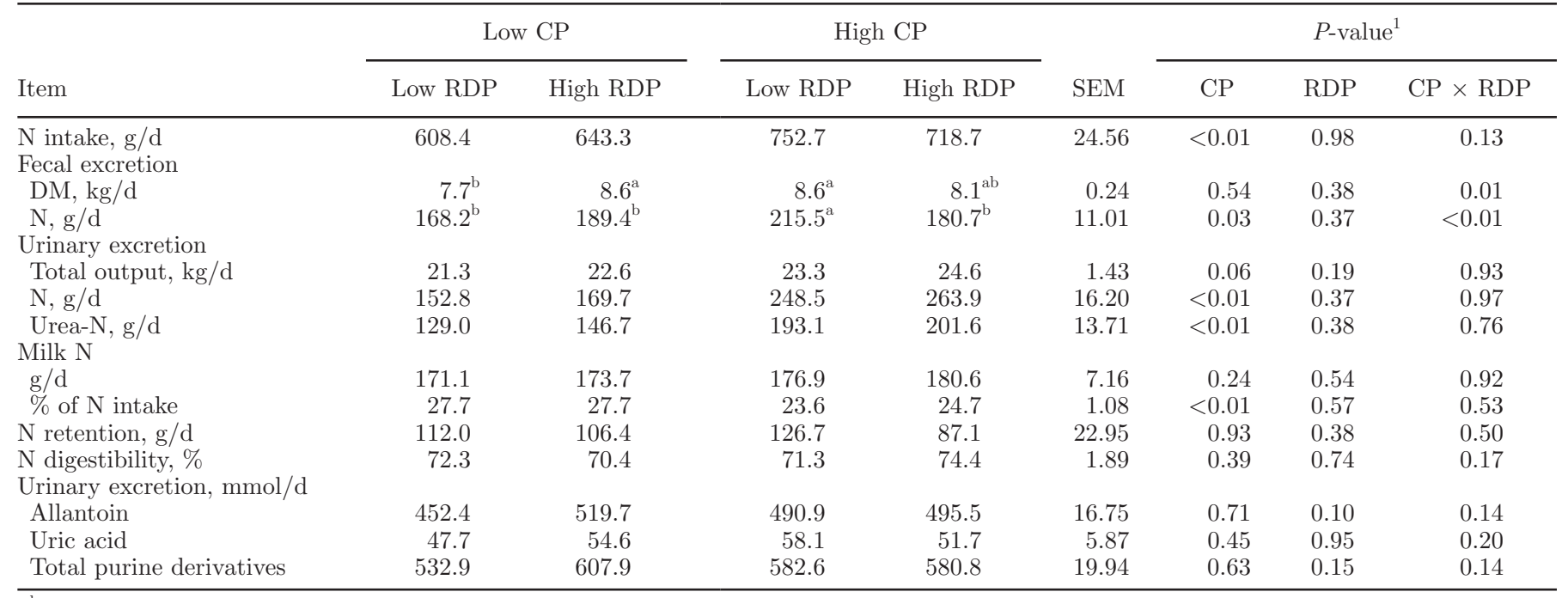

$\overline{\mathrm{a}, \mathrm{b}}$ Means within a row with different superscripts differ $(P<0.05)$.

${ }^{1} \mathrm{CP}=$ effect of dietary $\mathrm{CP}$ concentration; $\mathrm{RDP}=$ effect of dietary RDP concentration; $\mathrm{CP} \times \mathrm{RDP}=$ interaction. 
Table 6. Urea-nitrogen $(\mathrm{N})$ recycling kinetics as measured by continuous intrajugular infusions of $\left[{ }^{15} \mathrm{~N}^{15} \mathrm{~N}\right]$-urea in dairy cows $(\mathrm{n}=4)$ fed diets with low or high $\mathrm{CP}$ concentrations and containing low or high RDP concentrations

\begin{tabular}{|c|c|c|c|c|c|c|c|c|}
\hline \multirow[b]{2}{*}{ Item } & \multicolumn{2}{|c|}{ Low CP } & \multicolumn{2}{|c|}{ High CP } & \multirow[b]{2}{*}{ SEM } & \multicolumn{3}{|c|}{$P$-value ${ }^{1}$} \\
\hline & Low RDP & High RDP & Low RDP & High RDP & & $\mathrm{CP}$ & $\mathrm{RDP}$ & $\mathrm{CP} \times \mathrm{RDP}$ \\
\hline \multicolumn{9}{|c|}{ Urea-N flux, ${ }^{2} \mathrm{~g} / \mathrm{d}$} \\
\hline UER & 405.1 & 436.5 & 502.0 & 495.1 & 26.61 & $<0.01$ & 0.54 & 0.35 \\
\hline GER & 279.0 & 292.9 & 309.3 & 287.2 & 23.30 & 0.50 & 0.82 & 0.34 \\
\hline $\mathrm{ROC}$ & 213.3 & 230.4 & 251.0 & 252.1 & 16.39 & 0.05 & 0.47 & 0.52 \\
\hline UUE & 129.0 & 146.7 & 193.1 & 201.6 & 13.71 & $<0.01$ & 0.38 & 0.76 \\
\hline \multicolumn{9}{|c|}{ Fractional transfer } \\
\hline UER to urine & 0.31 & 0.33 & 0.40 & 0.41 & 0.027 & 0.02 & 0.45 & 0.84 \\
\hline UER to GIT & 0.69 & 0.67 & 0.60 & 0.56 & 0.027 & 0.02 & 0.45 & 0.84 \\
\hline GER to ROC & 0.76 & 0.78 & 0.85 & 0.88 & 0.029 & 0.03 & 0.47 & 0.91 \\
\hline GER to feces & 0.03 & 0.05 & 0.03 & 0.03 & 0.008 & 0.27 & 0.16 & 0.12 \\
\hline GER to UUA & 0.21 & 0.17 & 0.12 & 0.09 & 0.034 & 0.06 & 0.36 & 0.94 \\
\hline
\end{tabular}

${ }^{1} \mathrm{CP}=$ effect of dietary $\mathrm{CP}$ concentration; $\mathrm{RDP}=$ effect of dietary RDP concentration; $\mathrm{CP} \times \mathrm{RDP}=$ interaction.

${ }^{2} \mathrm{UER}=$ urea-N entry rate; UUE $=$ urinary urea-N elimination; GER = GIT entry rate; UFE = urea-N in feces; ROC $=$ urea-N returned to the ornithine cycle; UUA = urea-N utilized for anabolism; GIT = gastrointestinal tract.

$\mathrm{CP} \operatorname{diet}($ Table 6). Urea-N that was transferred to the GIT (i.e., GER) was unaffected by diet; however, when expressed as a proportion of UER, urea-N transfer to the GIT (i.e., GER:UER) was lower $(P=0.02)$ in cows fed the high-CP diet compared with those fed the low$\mathrm{CP}$ diet. Urea- $\mathrm{N}$ that was returned to the ornithine cycle, expressed in absolute amounts (i.e., ROC; $P=$ $0.05)$ or as a proportion of GER (i.e., GER to ROC; $P=0.03$ ), was greater in cows fed the high-CP diet compared with those fed the low-CP diet. Also, urea$\mathrm{N}$ that was excreted in urine, expressed in absolute amounts (i.e., UUE; $P<0.01$ ) or as a proportion of UER (i.e., UER to urine; $P=0.02$ ), was greater in cows fed the high-CP diet compared with those fed the low-CP diet. Urea-N that was used for anabolic purposes, expressed in absolute amounts (i.e., UUA; $P$ $=0.07$ ) or as a proportion of GER (i.e., GER to UUA; $P=0.06)$, tended to be lower in cows fed the high-CP diet compared with those fed the low-CP diet. Dietary $\mathrm{RDP}$ content did not affect urea-N fluxes or fractional transfers (Table 6).

\section{Milk Production and Composition}

Milk yield and milk composition were unaffected by dietary treatment (Table 7). For milk component yields, protein and lactose were unaffected by dietary treatment; however, on the low-CP diets, milk fat yield was greater for cows fed the low-RDP diet compared with those fed the high-RDP diet but was unaffected by $\mathrm{RDP}$ concentration on the high-CP diets (interaction, $P=0.05)$. On the high-CP diets, MUN concentration was greater in cows fed the high-RDP diet compared with those fed the low-RDP diet but was unaffected by $\mathrm{RDP}$ concentration on the low-CP diets (interaction, $P<0.01)$.

Table 7. Milk production and composition in dairy cows $(\mathrm{n}=8)$ fed diets with low or high CP concentrations and containing low or high RDP concentrations

\begin{tabular}{|c|c|c|c|c|c|c|c|c|}
\hline \multirow[b]{2}{*}{ Variable } & \multicolumn{2}{|c|}{ Low CP } & \multicolumn{2}{|c|}{ High CP } & \multirow[b]{2}{*}{ SEM } & \multicolumn{3}{|c|}{$P$-value ${ }^{1}$} \\
\hline & Low RDP & High RDP & Low RDP & High RDP & & $\mathrm{CP}$ & $\mathrm{RDP}$ & $\mathrm{CP} \times \mathrm{RDP}$ \\
\hline $3.5 \% \mathrm{FCM}, \mathrm{kg} / \mathrm{d}$ & 39.3 & 38.4 & 39.4 & 39.4 & 0.71 & 0.15 & 0.25 & 0.18 \\
\hline Fat, $\%$ & 3.68 & 3.53 & 3.60 & 3.50 & 0.158 & 0.66 & 0.29 & 0.82 \\
\hline Fat, $\mathrm{kg} / \mathrm{d}$ & $1.43^{\mathrm{a}}$ & $1.30^{\mathrm{b}}$ & $1.40^{\mathrm{a}}$ & $1.38^{\mathrm{a}}$ & 0.037 & 0.27 & 0.01 & 0.05 \\
\hline Protein, \% & 3.30 & 3.25 & 3.28 & 3.28 & 0.118 & 1.00 & 0.70 & 0.70 \\
\hline Lactose, $\mathrm{kg} / \mathrm{d}$ & 1.73 & 1.75 & 1.78 & 1.80 & 0.064 & 0.21 & 0.51 & 1.00 \\
\hline MUN, mg/dL & $12.3^{\mathrm{c}}$ & $13.0^{\mathrm{c}}$ & $16.0^{\mathrm{b}}$ & $19.5^{\mathrm{a}}$ & 0.93 & $<0.01$ & $<0.01$ & $<0.01$ \\
\hline
\end{tabular}

${ }^{\mathrm{a}-\mathrm{c}}$ Means within a row with different superscripts differ $(P<0.05)$.

${ }^{1} \mathrm{CP}=$ effect of dietary $\mathrm{CP}$ concentration; $\mathrm{RDP}=$ effect of dietary RDP concentration; $\mathrm{CP} \times \mathrm{RDP}=$ interaction. 


\section{DISCUSSION}

A primary objective of the current study was to determine how interactions between dietary $\mathrm{CP}$ and RDP contents alter whole-body urea-N kinetics in dairy cows; however, no interactions were detected for the major variables quantifying urea-N kinetics. Dietary RDP content was manipulated by feeding unprocessed or micronized canola meal. Chemical analysis confirmed that micronized canola meal had a lower soluble CP content and greater ADIN and NDIN contents compared with unprocessed canola meal, suggesting that our experimental approach of reducing dietary RDP by feeding micronized canola meal was sound. Except for the lowCP-low-RDP diet, we achieved our target dietary RDP contents of 61 and $69 \%$ (as percentage of $\mathrm{CP}$ ). Ruminal $\mathrm{NH}_{3}-\mathrm{N}$ concentrations were altered by both dietary $\mathrm{CP}$ and RDP contents, which would be reflective of changes in the extent of ruminal $\mathrm{CP}$ degradation. It is somewhat surprising, therefore, that we did not observe any interactions between dietary $\mathrm{CP}$ and RDP contents on urea-N kinetics. Most of the major dietary effects on urea-N kinetics that we observed were attributed to dietary $\mathrm{CP}$ content, so it is plausible that the $8 \%$ unit difference in dietary RDP content was not large enough to elicit responses in urea-N kinetics.

Endogenous urea-N (UER) production in the present study ranged from 405 to $502 \mathrm{~g} / \mathrm{d}$ (mean of $460 \mathrm{~g} / \mathrm{d}$ ) across dietary treatments, which is in agreement with UER values (305-483 g/d, Gozho et al., 2008; 384-504 $\mathrm{g} / \mathrm{d}$, Chibisa and Mutsvangwa, 2013) that our research group has reported previously in dairy cows at similar $\mathrm{N}$ intakes and using the same intrajugular $\left[{ }^{15} \mathrm{~N}^{15} \mathrm{~N}\right]$-urea infusion protocol as used in the present study. Across dietary treatments, the UER:digestible $\mathrm{N}$ intake ratios were 0.92 to 0.96 , which fall within the range of 0.43 to 1.23 (mean of 0.88 ) that was reported previously (Lapierre and Lobley, 2001) for lactating cows at various levels of production and fed a wide variety of diets. Our results show that most of the digestible $\mathrm{N}$ intake passed through the urea-N pool on a daily basis, highlighting the importance of urea- $\mathrm{N}$ recycling as a mechanism to conserve $\mathrm{N}$ in ruminants. Indeed, GER:UER ratios (i.e., the proportion of endogenous urea- $\mathrm{N}$ that was transferred to the GIT) ranged from 0.56 to 0.69 across dietary treatments. Urea-N that is transferred from the bloodstream into the forestomachs provides additional $\mathrm{N}$ (as $\left.\mathrm{NH}_{3}-\mathrm{N}\right)$ that can support microbial growth when dietary N or RDP intakes are low (Lapierre and Lobley, 2001; Reynolds and Kristensen, 2008).

Our results showed that UER was greater in cows fed the high-CP diet compared with those fed the low-CP diet. Huntington and Archibeque (2000) conducted an extensive evaluation of experimental data on transhe- patic venous-arterial urea- $\mathrm{N}$ fluxes in beef and dairy cattle at variable $\mathrm{N}$ intakes and productive states and reported a strong, positive correlation $\left(\mathrm{r}^{2}=0.96\right)$ between $\mathrm{N}$ intake and hepatic output of urea-N. In the present study, cows fed the high-CP diet had a greater $\mathrm{N}$ intake compared with those fed the low-CP diet, so the greater UER in cows fed the high-CP diet is not surprising. Endogenous urea-N production is a consequence of ruminal microbial degradation of dietary $\mathrm{CP}$ to $\mathrm{NH}_{3}-\mathrm{N}$, with the resultant ruminal $\mathrm{NH}_{3}-\mathrm{N}$ that is not captured for microbial protein synthesis being absorbed into portal blood and converted to urea in the liver (Bach et al., 2005). Since ruminal absorption of $\mathrm{NH}_{3}-\mathrm{N}$ into portal blood is a concentration-dependent process, it is plausible that cows fed the high-CP diet absorbed more $\mathrm{NH}_{3}-\mathrm{N}$ because of their greater ruminal $\mathrm{NH}_{3}-\mathrm{N}$ concentration, which would result in a greater UER compared with cows fed the low-CP diet. More recently, other studies have also reported greater UER with increasing $\mathrm{N}$ intakes in sheep (Marini et al., 2004) and cattle (Archibeque et al., 2001; Marini and Van Amburgh, 2003; Chibisa and Mutsvangwa, 2013). The quantity of hepatic urea-N output that was transferred to the GIT (i.e., GER) was unaffected by dietary CP content; however, when expressed as a proportion of UER (0.58 vs. 0.68), GER was greater in cows fed the low-CP diet compared with those fed the high-CP diet. Among the numerous factors that have been reported to influence transepithelial movement of urea- $\mathrm{N}$ from the bloodstream into the rumen, ruminal $\mathrm{NH}_{3}-\mathrm{N}$ concentration has long been reported to have inhibitory effects on urea-N transfer (Kennedy and Milligan, 1980). The exact mechanisms involved in these inhibitory effects of ruminal $\mathrm{NH}_{3}-\mathrm{N}$ are unclear. Recently, Lu et al. (2014) postulated that ruminal uptake of ammonia $\left(\right.$ as $\mathrm{NH}_{4}{ }^{+}$) at physiological ruminal $\mathrm{pH}(<7)$ resulted in intracellular acidification that reduced the permeability of urea transporters to urea. In the present study, cows fed the low-CP diet exhibited a lower ruminal $\mathrm{NH}_{3}-\mathrm{N}$ concentration compared with those fed the high-CP diet, suggesting that the lower ruminal $\mathrm{NH}_{3}-\mathrm{N}$ concentration on the low-CP diet could have promoted a greater GER. Surprisingly, when GER was expressed in absolute amounts or as a proportion of UER, it was not altered by dietary RDP content even though ruminal $\mathrm{NH}_{3}-\mathrm{N}$ concentrations were different in cows fed the low-RDP diet compared with those fed the high-RDP diet. These results are incongruent with the inhibitory effects of high ruminal $\mathrm{NH}_{3}-\mathrm{N}$ concentration on GER that we observed with dietary $\mathrm{CP}$ content, and the reasons for this finding are unclear.

The amount of GER that was used for anabolic purposes (UUA), expressed in absolute amounts or as a proportion of GER, tended to be greater for cows fed 
the low-CP diet compared with those fed the high-CP diet. According to Lobley et al. (2000), most of the anabolic use of recycled urea-N (i.e., UUA) is predominantly as sequestration of liberated $\mathrm{NH}_{3}-\mathrm{N}$ into microbial protein that subsequently supplies amino acids to the host animal after postruminal digestion. Although we did not measure microbial NAN supply and the direct incorporation of recycled ${ }^{15} \mathrm{~N}$ into $\mathrm{MP}$, these data suggest a greater microbial incorporation of recycled urea- $\mathrm{N}$ into microbial protein. As dietary $\mathrm{N}$ intake and consequently the ruminal $\mathrm{NH}_{3}-\mathrm{N}$ pool decrease with the low-CP diet, ruminal bacteria become more dependent on recycled urea- $\mathrm{N}$ as a source of $\mathrm{NH}_{3}-\mathrm{N}$. Other studies also reported an increase in UUA in sheep (Kiran and Mutsvangwa, 2010) and dairy cows (Chibisa and Mutsvangwa, 2013) when dietary CP content was reduced. It is plausible that in the present study the additional $\mathrm{N}$ that was supplied via urea- $\mathrm{N}$ recycling could have maintained microbial growth in the face of a diminished dietary $\mathrm{N}$ supply. Concomitant with the tendency for a greater utilization of recycled urea- $\mathrm{N}$ for anabolic purposes, urea- $\mathrm{N}$ that was returned to the ornithine cycle (i.e., ROC; expressed in absolute amounts or as a proportion of GER) and urea-N eliminated in urine (i.e., UUE; expressed in absolute amounts or as a proportion of UER) were lower in cows fed the low-CP diet compared with those fed the high-CP diet, suggesting improved $\mathrm{N}$ efficiency in cows fed the low-CP diet.

Production performance (i.e., milk yield and milk composition) were largely unaffected by altering dietary $\mathrm{CP}$ and RDP contents. Reducing dietary $\mathrm{CP}$ content can decrease feed costs and $\mathrm{N}$ losses to the environment (Olmos Colmenero and Broderick, 2006; Hristov et al., 2011). On average, milk yield was $38.8 \mathrm{~kg} / \mathrm{d}$ and did not differ among diets in the present study, demonstrating that at least in the short term cows fed $14.9 \% \mathrm{CP}$ can maintain similar levels of milk yield compared with cows fed $17.5 \% \mathrm{CP}$. We can speculate that the ability to maintain high levels of milk yield with the low-CP diet in the present study could partly be attributed to the maintenance of microbial protein production due to enhanced urea-N recycling, such that MP flow at the small intestine was not compromised. However, these data should be interpreted somewhat cautiously because this was a short-term (8-d measurement period) feeding study, and further research is warranted to determine production responses to feeding low-CP diets for longer periods (e.g., for a full lactation). This caution is because perusal of the literature indicates that responses in milk production to reducing dietary $\mathrm{CP}$ content have been equivocal. Previous research has reported that feeding a diet containing $15.2 \% \mathrm{CP}$ compared with $17.3 \% \mathrm{CP}$ lowered milk yield by $3 \mathrm{~kg} / \mathrm{cow}$ per day (Chibisa and Mutsvangwa, 2013), a response that was partly attributed to a decrease in MP supply at the small intestine. As expected, cows fed the high$\mathrm{CP}$ diet excreted more $\mathrm{N}$ compared with cows fed the low-CP diet, with this response being due to a greater urinary $\mathrm{N}$ excretion (rather than fecal $\mathrm{N}$ excretion) as has been reported by others (Olmos Colmonero and Broderick, 2006; Lee et al., 2011). As a result, MNE improved when we fed the low-CP diet, and this outcome is in agreement with previous studies (Olmos Colmenero and Broderick, 2006; Chibisa and Mutsvangwa, 2013). Again, dietary RDP content had no major effects on $\mathrm{N}$ excretion or MNE. Across dietary treatments, total N excretion as a proportion of $\mathrm{N}$ intake ranged from 52.8 to $61.7 \%$, which falls within the range that is typically reported in the literature (Castillo et al., 2001; Chibisa and Mutsvangwa, 2013). Another indicator of $\mathrm{N}$ use that we measured was MUN concentration. Feeding the low-CP diet resulted in a lower MUN concentrations compared with feeding the high-CP diet, as has been reported in other studies in which dietary $\mathrm{CP}$ content has been manipulated (Olmos Colmenero and Broderick, 2006, Lee et al., 2011; Chibisa and Mutsvangwa, 2013). Low concentrations of MUN suggest efficient use of dietary CP (Olmos Colmenero and Broderick, 2006). In dairy cows, MUN arises from endogenous synthesis of urea- $\mathrm{N}$ in the liver using ruminally derived $\mathrm{NH}_{3}-\mathrm{N}$ (NRC, 2001). Because cows fed the low-CP diet exhibited a lower ruminal $\mathrm{NH}_{3}-\mathrm{N}$ concentration compared with cows fed the high-CP diet, it is not surprising that MUN concentration in cows fed the low-CP diet was lower. Altering dietary RDP content had no major effects on production performance and $\mathrm{N}$ utilization.

As expected, the major effects of altering dietary $\mathrm{CP}$ and RDP contents on patterns of ruminal fermentation were observed in changes in ruminal $\mathrm{NH}_{3}-\mathrm{N}$ concentration. As discussed elsewhere in this article, ruminal $\mathrm{NH}_{3}-\mathrm{N}$ concentration is positively correlated with both dietary CP and RDP intakes (Seal and Reynolds, 1993; Reynolds and Kristensen, 2008), so manipulating dietary $\mathrm{N}$ and RDP intakes was expected to alter ruminal $\mathrm{NH}_{3}-\mathrm{N}$ concentration. Other studies in dairy cows have reported a decrease in ruminal $\mathrm{NH}_{3}-\mathrm{N}$ concentrations as dietary CP (Reynal and Broderick, 2005; Chibisa and Mutsvangwa, 2013) or dietary RDP (Chibisa and Mutsvangwa, 2013) concentrations are reduced. $\mathrm{Ru}-$ minal $\mathrm{NH}_{3}-\mathrm{N}$ is the major source of $\mathrm{N}$ for microbial growth (Brito et al., 2007); for that reason, many studies have sought to determine the minimum ruminal $\mathrm{NH}_{3}-\mathrm{N}$ concentration that is required for maximum microbial protein synthesis. Earlier studies (Satter and Slyter, 1974) reported that minimum ruminal $\mathrm{NH}_{3}-\mathrm{N}$ concentration to be $5 \mathrm{mg} / \mathrm{dL}$; however, more recent studies (Balcells et al., 1993; Reynal and Broderick, 
2005) have reported that the minimum ruminal $\mathrm{NH}_{3}-\mathrm{N}$ concentration to maximize microbial protein synthesis was $11 \mathrm{mg} / \mathrm{dL}$. In the present study, ruminal $\mathrm{NH}_{3}-\mathrm{N}$ concentrations on all diets were always above $11 \mathrm{mg} /$ $\mathrm{dL}$ at all sampling times during a 24-h feeding cycle (data not shown) so it is unlikely that ruminal $\mathrm{NH}_{3}-\mathrm{N}$ was deficient on any diet. Ruminal concentrations of total and individual SCFA were largely unaltered by dietary treatment, except that ruminal concentrations of isobutyrate and isovalerate were greater in cows fed the high-RDP diet compared with those fed the lowRDP diet. These branched-chain SCFA are produced from the ruminal degradation of branched-chain amino acids (Johnson et al., 1994), so the greater RDP intake in cows fed the high RDP diet could have provided more precursors for branched-chain SCFA production.

Altering dietary $\mathrm{CP}$ also affected fiber digestion. Apparent ruminal fiber digestion, expressed in absolute amounts or as a proportion of fiber intake, was greater in cows fed the low-CP diet compared with those fed the high-CP diet. Also, the same trend was observed for total-tract fiber digestion, thus suggesting that the lower ruminal fiber digestion with the high-CP diet was not compensated by a greater postruminal fiber digestion. Chibisa and Mutsvangwa (2013) also reported greater ruminal fiber digestion when dietary $\mathrm{CP}$ content was reduced from 17.3 to $15.2 \%$, which are CP contents similar to what was used in the present study. Others (Firkins et al., 1986; Allen, 2000) have reported that an insufficient RDP supply (due to feeding low-CP or lowRDP diets) can potentially reduce fiber digestion by reducing microbial growth; however, our observations are not in agreement with these findings. It is noteworthy that ruminal $\mathrm{NH}_{3}-\mathrm{N}$ concentrations were well above the minimum concentration $(11 \mathrm{mg} / \mathrm{dL}$; Balcells et al., 1993; Reynal and Broderick, 2005) that is required to support microbial growth, which could partly explain why ruminal fiber digestion was not suppressed with the low-CP diets.

\section{CONCLUSIONS}

In summary, ruminal $\mathrm{NH}_{3}-\mathrm{N}$ concentrations were altered by lowering diet $\mathrm{CP}$ and RDP concentrations. However, increases in the fractional transfer of UER to the GIT compensated for reduced ruminal $\mathrm{NH}_{3}-\mathrm{N}$ concentrations and allowed for the maintenance of microbial protein supply as evidenced by the tendency for a greater UUA with the low-CP diet compared with the high-CP diet in this short-term study. Even though both dietary CP and RDP concentrations were reduced, milk yield did not decrease. In addition, as dietary $\mathrm{CP}$ concentration was reduced, urinary $\mathrm{N}$ excretion also declined. Lowering $\mathrm{N}$ excretion not only improves $\mathrm{N}$ efficiency but also reduces the negative environmental impact of intensive livestock operations. Although our results showed that lowering the concentration of $\mathrm{CP}$ from 17.5 to $14.9 \%$ had no detrimental effects on milk production, it should be noted that the long-term effects on milk production and reproductive performance from reducing dietary CP concentration to $14.9 \%$ are unknown; therefore, long-term lactation studies are warranted to investigate the effects of low-CP diets on animal performance.

\section{REFERENCES}

Ahvenjarvi, S., A. Vanhatalo, P. Huhtanen, and T. Varvikko. 2000. Determination of reticulo-rumen and whole-stomach digestion in lactating cows by omasal canal or duodenal sampling. Br. J. Nutr. 83:67-77.

Allen, M. S. 2000. Effects of diet on short-term regulation of feed intake by lactating dairy cattle. J. Dairy Sci. 83:1598-1624.

AOAC. 1990. Official Methods of Analysis. 15th ed. Association of Official Analytical Chemists, Arlington, VA.

AOAC International. 2002. Official Methods of Analysis. 17th ed. AOAC Int., Arlington, VA.

Archibeque, S. L., J. C. Burns, and G. B. Huntington. 2001. Urea flux in beef steers: Effects of forage species and nitrogen fertilization. J. Anim. Sci. 79:1937-1943.

Bach, A., S. Calsamiglia, and M. D. Stern. 2005. Nitrogen metabolism in the rumen. J. Dairy Sci. 88(E. Suppl.):E9-E21.

Balcells, J., J. A. Guada, C. Castrillo, and J. Gasa. 1993. Rumen digestion and urinary excretion of purine derivatives in response to urea supplementation of sodium-treated straw fed to sheep. Br. J. Nutr. 69:721-732.

Brito, A. F., G. A. Broderick, and S. M. Reynal. 2007. Effects of different protein supplements on omasal nutrient flow and microbial protein synthesis in lactating dairy cows. J. Dairy Sci. 90:18281841.

Broderick, G. A., and J. H. Kang. 1980. Automated and simultaneous determination of ammonia and total amino acids in ruminal fluids and in vitro media. J. Dairy Sci. 63:64-75.

Cabrita, A. R. J., R. J. Dewhurst, D. S. Melo, J. M. Mororby, and A. J. M. Fonseca. 2011. Effects of dietary protein concentration and balance of absorbable amino acids on productive responses of dairy cows fed corn silage-based diets. J. Dairy Sci. 94:4647-4656.

Canadian Council on Animal Care. 1993. Guide to the Care and Use of Experimental Animals. 2nd ed. Vol. 1. CCAC, Ottawa, ON, Canada.

Castillo, A. R., E. Kebreab, D. E. Beever, and J. France. 2001. A review of efficiency of nitrogen utilization in lactating dairy cows and its relationship with environmental pollution. J. Anim. Feed Sci. 9:1-32.

Chase, L. E., R. J. Higgs, and M. E. Van Amburgh. 2009. Feeding low crude protein rations to dairy cows - Opportunities and challenges. Proc. Cornell Nutr. Conf. Feed Manufacturers. Cornell University Press, Ithaca, NY.

Chen, X. B., and M. J. Gomes. 1992. Estimation of microbial protein supply to sheep and cattle based on urinary excretion of purine derivatives - An overview of the technical details. Int. Feed Resources Unit, Rowett Research Institute, Aberdeen, UK.

Cheng, K. J., and R. J. Wallace. 1979. The mechanism of passage of endogenous urea through the rumen wall and the role of ureolytic epithelial bacteria in the urea flow. Br. J. Nutr. 42:553-557.

Chibisa, G. E., and T. Mutsvangwa. 2013. Effects of feeding wheat or corn-wheat dried distillers grains with solubles in low or high crude protein diets on ruminal function, omasal nutrient flows, urea-N recycling, and performance in cows. J. Dairy Sci. 96:6550-6563. 
Cowling, E. B., and J. N. Galloway. 2002. Challenges and opportunities facing animal agriculture: Optimizing nitrogen management in the atmosphere and biosphere of the Earth. J. Anim. Sci. 80:E157E167.

Egan, A. R., K. Boda, and J. Varady. 1986. Regulation of nitrogen metabolism and recycling. Pages 386-402 in Control of Digestion and Metabolism in Ruminants. L. P. Milligan, W. L. Grovum, and A. Dobson, ed. Prentice-Hall, Englewood Cliffs, NJ.

Erwin, E. S., G. J. Marco, and E. M. Emery. 1961. Volatile fatty acids analysis of blood and rumen fluid by gas chromatography. J. Dairy Sci. 44:1768-1776.

Firkins, J. L., L. L. Berger, N. R. Merchen, G. C. Fahey Jr., and D. R. Nelson. 1986. Effects of feed intake and protein degradability on ruminal characteristics and site of digestion in steers. J. Dairy Sci. 69:2111-2123.

Fossati, P., L. Prencipe, and G. Berti. 1980. Use of 3,5-dichloro-2-hydroxybenzenesulfonic acid/4-aminophenazone chromogenic system in direct enzymic assay of uric acid in serum and urine. Clin. Chem. 26:227-231.

France, J., and R. C. Siddons. 1986. Determination of digesta flow by continuous marker infusion. J. Theor. Biol. 121:105-119.

Gozho, G. N., M. R. Hobin, and T. Mutsvangwa. 2008. Interactions between barley grain processing and source of supplemental dietary fat on nitrogen metabolism and urea-nitrogen recycling in dairy cows. J. Dairy Sci. 91:247-259.

Hristov, A. N., M. Hanigan, A. Cole, R. Todd, T. A. McAllister, P M. Ndegwa, and A. Rotz. 2011. Review: Ammonia emissions from dairy farms and beef feedlots. Can. J. Anim. Sci. 91:1-35.

Huhtanen, P., P. G. Brotz, and L. D. Satter. 1997. Omasal sampling technique for assessing fermentative digestion in the forestomach of dairy cows. J. Anim. Sci. 75:1380-1392.

Huntington, G. B., and S. L. Archibeque. 2000. Practical aspects of urea and ammonia metabolism in ruminants. J. Anim. Sci. 77(ESuppl. 1):1-11.

Johnson, T. R., M. J. Cecava, E. B. Sheiss, and K. D. Cunningham. 1994. Additions of ruminally degradable crude protein and branched-chain volatile fatty acids to diets containing hydrolyzed feather meal and blood meal for lactating cows. J. Dairy Sci. $77: 3676-3682$

Kennedy, P. M., and L. P. Milligan. 1980. The degradation and utilization of endogenous urea in the gastrointestinal tract of ruminants: A review. Can. J. Anim. Sci. 60:205-221.

Kiran, D., and T. Mutsvangwa. 2010. Effects of partial defaunation on urea-nitrogen recycling, nitrogen metabolism, and microbial nitrogen supply in growing lambs fed low or high dietary crude protein concentrations. J. Anim. Sci. 88:1034-1047.

Lapierre, H., and G. E. Lobley. 2001. Nitrogen recycling in the ruminant: A review. J. Dairy Sci. 84(Suppl.):E223-E236.

Lee, C., A. N. Hristov, K. S. Heyler, T. W. Cassidy, M. Long, B. A. Corl, and S. K. R. Karnati. 2011. Effects of dietary protein concentration and coconut oil supplementation on nitrogen utilization and production in dairy cows. J. Dairy Sci. 94:5544-5557.

Licitra, G., T. M. Hernandez, and P. J. Van Soest. 1996. Standardization of procedures for nitrogen fractionation of ruminant feeds. Anim. Feed Sci. Technol. 57:347-358.

Lobley, G. E., D. M. Bremner, and G. Zuur. 2000. Effects of diet quality on urea fates in sheep as assessed by refined, non-invasive $\left.{ }^{15} \mathrm{~N}^{15} \mathrm{~N}\right]$ urea kinetics. Br. J. Nutr. 84:459-468.

Lu, Z., F. Stumpff, C. Deiner, J. Rosendahl, H. Braun, K. Abdoun, J. R. Aschenbach, and H. Martens. 2014. Modulation of sheep ru- minal urea transport by ammonia and pH. Am. J. Physiol. Regul. Integr. Comp. Physiol. 307:R558-R570.

Marini, J. C., J. D. Klein, J. M. Sands, and M. E. Van Amburgh. 2004. Effect of nitrogen intake on nitrogen recycling and urea transporter abundance in lambs. J. Anim. Sci. 82:1157-1164.

Marini, J. C., and M. E. Van Amburgh. 2003. Nitrogen metabolism and recycling in Holstein heifers. J. Anim. Sci. 81:545-552.

National Research Council. 2001. Nutrient Requirements of Dairy Cattle. 7th rev. ed. National Academy Press, Washington, DC.

Olmos Colmenero, J. J., and G. A. Broderick. 2006. Effect of dietary crude protein concentration on milk production and nitrogen utilization in lactating dairy cows. J. Dairy Sci. 89:1704-1712.

Rémond, D., F. Meschy, and R. Boivin. 1996. Metabolites, water and mineral exchanges cross the rumen wall: Mechanisms and regulation. Ann. Zootech. 45:97-119.

Reynal, S. M., and G. A. Broderick. 2005. Effect of dietary level of rumen-degraded protein on production and nitrogen metabolism in lactating dairy cows. J. Dairy Sci. 88:4045-4064.

Reynal, S. M., G. A. Broderick, and C. Bearzi. 2005. Comparison of four markers for quantifying microbial protein flow from the rumen of lactating dairy cows. J. Dairy Sci. 88:4065-4082.

Reynolds, C. K., and N. B. Kristensen. 2008. Nitrogen recycling through the gut and the nitrogen economy of ruminants: An asynchronous symbiosis. J. Anim. Sci. 86(E. Suppl.):E293-E305.

Roe, M. B., C. J. Sniffen, and L. E. Chase. 1990. Techniques for measuring protein fractions in feedstuffs. Page 81 in Proc. Cornel Nutr. Conf., Ithaca, NY.

SAS Institute. 2004. SAS/STAT 9.1 User's Guide. SAS Institute Inc., Cary, NC.

Satter, L. D., and L. L. Slyter. 1974. Effect of ammonia concentration on rumen microbial protein production in vitro. Br. J. Nutr. 32:199-208.

Seal, C. J., and C. K. Reynolds. 1993. Nutritional implications of gastrointestinal and liver metabolism in ruminants. Nutr. Res. Rev. 6:185-208

Siddons, R. C., J. V. Nolan, D. E. Beever, and J. C. MacRae. 1985 Nitrogen digestion and metabolism in sheep consuming diets containing contrasting forms and levels of N. Br. J. Nutr. 54:175-187.

Udén, P., P. E. Colucci, and P. J. Van Soest. 1980. Investigation of chromium, cerium and cobalt as markers in digesta: Rate of passage studies. J. Sci. Food Agric. 31:625-632.

Van Soest, P. J., J. B. Robertson, and B. A. Lewis. 1991. Methods for dietary fiber, neutral detergent fiber and non-starch polysaccharides (NSP) in relation to animal nutrition. J. Dairy Sci. $74: 3583-3597$.

Vicente, F., A. Sarraseca, A. de Vega, and J. A. Guada. 2004. Performance of several $\mathrm{Cr}$ and $\mathrm{Yb}$ analytical techniques applied to samples of different biological origin (digesta or faeces). J. Sci. Food Agric. 84:2035-2040.

Wickersham, T. A., E. C. Titgemeyer, R. C. Cochran, E. E. Wickersham, and D. P. Gnad. 2008a. Effect of rumen-degradable intake protein supplementation on urea kinetics and microbial use of recycled urea in steers consuming low-quality forage. J. Anim. Sci. 86:3079-3088

Wickersham, T. A., E. C. Titgemeyer, R. C. Cochran, E. E. Wickersham, and E. S. Moore. 2008b. Effect of frequency and amount of rumen-degradable intake protein supplementation on urea kinetics and microbial use of recycled urea in steers consuming low-quality forage. J. Anim. Sci. 86:3089-3099. 